\title{
Comparison Analysis of Regency Performance after Area Expantion in Bengkulu Province
}

\author{
Armelly $^{1}$, Novi Tri Putri ${ }^{2}$, Esti Pasaribu ${ }^{3}$, Ratu Eva Febriani ${ }^{4}$ \\ Department of Development Economics, Bengkulu University, Bengkulu, Indonesia ${ }^{1,2,3,4}$ \\ \{armelly@unib.ac.id ${ }^{1}$,novitriputri@unib.ac.id², estipasaribu@unib.ac.id ${ }^{3}$, ratuevafebriani@unib.ac.id $\left.{ }^{4}\right\}$
}

\begin{abstract}
This study aims to analyze the performance of old and new regency in Bengkulu Province. As we know that an area expantion must be follow with the changing of structure economy. This study comparing whether an expantion making the bettter structure in economic growth. All of data used in this study are time series data and processed using Williamson Index and Klassen Typology. The empirical results of this study indicate that almost in the all regencies showing that new regency are more developed than the old. But in general, after the expantion, there are improvement in both economic growth and also GRDP per capita. So, an area expantion causing positif effect for regional economic growth.
\end{abstract}

Keywords: Williamson Index; Klassen Typology

\section{Introduction}

Regional expantion certainly affects the performance of the regional economy. In addition, the expantion of the region causes administrative areas within a province to become more numerous and will affect the inequality of existing development. The results of Putri and Almahmudi's research showed the development of development inequality in Bengkulu Province represented by Williamson Index (WI) at three observation points related to the expantion of the region.

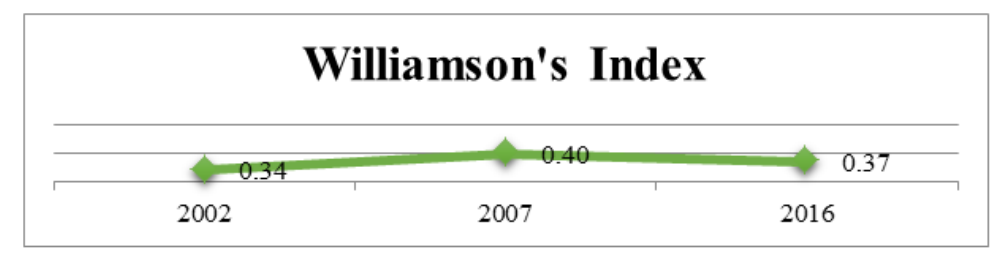

Source: Putri \& Almahmudi (2018)

Fig.1. Williamson Index of Bengkulu in period 2002, 2007 and 2016

From three years of observation, it appears that the highest WI was in 2007 or after the formation of 5 new regencys. This figure shows that inter-regency development in Bengkulu Province is becoming more lame than in 2002. If it associated with the expantion of the region, development inequality can be higher if the regions resulting from the expantion have 
relatively low economic performance or cannot develop properly. This is very likely because new regions usually have not been able to optimize the existing economic potential including lag in governance and economic activities due to the separate from the main regency.

In addition to the influence of regional economic performance, development inequality can also be higher if the parent region loses the source of economic growth derived from the population with relatively higher productivity. This will result in the parent regency experiencing a decline in economic performance which has an impact on the lower per capita income of the region.

Arianti \& Cahyadinata (2013) research results on the impact of regional expantion in coastal areas of Bengkulu Province showed that from 3 indicators of economic performance, only GRDP per capita was shown to change where the GRDP per capita after regional expantion was higher than before the expantion. While the other indicators, economic growth and poverty rates, are constant. Classification of regencies/cities in Bengkulu Province in 2016 can be seen in table 1. It is seen that the 3 main regencies that experienced regional expantion have per capita income below the average of Bengkulu Province.

Table 1. Classification of Regency/City of Bengkulu Province in 2016

\begin{tabular}{llll}
\hline $\mathbf{Y}$ & \multicolumn{1}{c}{$\mathbf{R i}<\mathbf{4 . 7 3 \%}$} & \multicolumn{1}{c}{$\mathbf{R i}>\mathbf{4 . 7 3 \%}$} \\
\hline $\mathbf{Y i}>\mathbf{2 1 b i l l i o n}$ & $\begin{array}{l}\text { Regency/city advanced but depressed: } \\
\text { Central Bengkulu }\end{array}$ & $\begin{array}{l}\text { Regency/city developed and growing fast: } \\
\text { Bengkulu }\end{array}$ \\
$\mathbf{Y i}<\mathbf{2 1 b i l l i o n}$ & $\begin{array}{l}\text { Under developed regency: North } \\
\text { Bengkulu, Rejang Lebong. Seluma \& } \\
\text { Lebong }\end{array}$ & $\begin{array}{l}\text { Fast growing regency/city : South Bengkulu. } \\
\text { Kaur. Kepahiang \& Mukomuko }\end{array}$ \\
\hline
\end{tabular}

Source: Putri \& Almahmudi (2018)

The main requirement for economic development is that the growth process must rely on the economic capability in the region. Development is impossible if it is not in accordance with the wishes of the local community. The lack of community support will cause economic development to stall (Jhingan, 1985.)

Dhyatmika and Atmanti (2013) saw the influence of regional expantion on economic development in Banten Province. As a result, after the expantion of the region there was an increase in economic growth, but inequality also grew. The same is also concluded in the research of Santika, Santoso, and Mahmudi (2018).

To get a clearer picture of the development of regional expantion, especially the comparison of economic performance of the main regency, the study aims to analyze the performance comparison of each parent regency with the region of its expantion in Bengkulu Province.

\section{Literature Review and Hypothesis}

\section{Regional Expantion and Disparity between Regions}

Regional expantion in Indonesia is the establishment of new administrative areas at the provincial and city and regency levels of their parent. The legal basis for regional expantion in Indonesia is Law No. 32/2004 on Local Government (Kuncoro, 2012). Furthermore, it is explained that the fundamental reason for the expantion of the region is the improvement of the welfare of local communities. During this time, resources tend to be drawn to the parent area so that areas far from the center of power are left behind. 
The World Bank concluded that there are 4 main drivers of regional expantion, namely (Herawati):

a. Motives for the effectiveness of government administration considering the area of such a large area, the population is spreading and there is a lag in development.

b. Tendency to homogeneity (ethnic, language, religious, urban rural, income level). Some regional expantion is more based on the motive of wanting to escape from the "oppression" of other groups on the basis of ethnicity, religion, and others.

c. The existence of fiscal indulgence guaranteed by the Law with the provision of DAU, DAK, Revenue Share from Natural Resources and the provision of regional revenue sources.

d. Motives of rente hunters from the elites. The expantion of many areas is based on motives because they want to serve in the Local Bureaucracy and the DPRD. In addition, the expantion of the region is also based on the motive to rebuild the history and power of the old aristocracy that had been pudak in the past.

Regional expantion according to Law No. 32 of 2004 is expected: First, able to improve the quality and equality of services to the community. Second, it is able to increase the acceleration of economic development, especially in the suburbs. Third, facilitate the growth of democratic life in the region. Fourth, increase security and order in the area. Fifth, contribute to unity and nationality.

The regional expantion evaluation study conducted by Bappenas \& UNDP (2008) used several study focus indicators, namely Regional Economy, Regional Finance, Public Services and Local Government Apparatus, based on PP 129/2000. Indicators used as a measure of regional economic performance are: Growth of non-oil and gas GDP, GDP per capita, ratio of regency GDP to provincial GDP, and poverty rate.

Local government financial performance is measured through indicators of Fiscal Dependency, Revenue Creation Capacity, Proportion of Capital Expenditure, and Government Sector Contribution. For a measure of public service performance, it is focused on services in the fields of education, health and infrastructure. Indicators used are Number of Shiva per School, Number of Students per Teacher, Availability of Health Facilities, Availability of Health Workers and Infrastructure Quality.

The last focus indicator of the study was the Performance of Local Government Apparatus which is used to find out how far the availability of apparatus can meet the demands of service to the community. Three indicators that point to the availability and quality of government apparatus are The Quality of Education Apparatus, Percentage of Educator Apparatus and Percentage of Paramedic Apparatus.

\section{Methodology}

Williamson Index (WI) is one of the methods that can be used to analyze disparities between regions. The usefulness of calculating this index is to determine the inequality of economic development between regions in one region. A component that is often used as an indicator of regional development is per capita income. However, the calculation of disparity between regions with the Williamson Index can also be done using variables other than per capita income, for example used per capita investment variables to see how much inequality of investment absorption between regions in one region. The Williamson Index is formulated as follows: 


$$
W I=\frac{\sqrt{\sum_{i=1}^{n}(Y i-Y)^{2} * P i / P}}{Y}
$$

Where: $\mathrm{WI}=$ Williamson Index, $\mathrm{Yi}=$ Per capita income of the region $\mathrm{i}$ which is part of the researched area, $\mathrm{Y}=$ Per capita income of the region studied, $\mathrm{Pi}=$ Number of residents of the region $\mathrm{i}$, and $\mathrm{P}=$ Total population of the region studied.

This Williamson Index formula will produce index numbers ranging from $0-1$. The index number $=0$ indicates that there are no economic gaps between regions in the region studied. An index number greater than 0 indicates a gap between regions. The larger the index number means the greater the level of economic inequality between regions.

Table 2. Classification of Regions Based on Klassen Typology

\begin{tabular}{|c|c|c|}
\hline $\mathrm{Y}^{R}$ & $\mathbf{R i}<\mathbf{R}$ & $\mathbf{R i}>\mathbf{R}$ \\
\hline $\begin{array}{l}\mathbf{Y i}>\mathbf{Y} \\
\mathbf{Y i}<\mathbf{Y}\end{array}$ & $\begin{array}{l}\text { Developed but depressed areas } \\
\text { Underdeveloped areas }\end{array}$ & $\begin{array}{l}\text { Fast-growing and advanced areas } \\
\text { Fast-growing areas }\end{array}$ \\
\hline
\end{tabular}

Where: $\mathrm{Ri}=\mathrm{GDP}$ growth rate $\mathrm{i}$ region, $\mathrm{R}=$ gdp growth rate of region, $\mathrm{Yi}=$ per capita income of region $\mathrm{i}, \mathrm{Y}=$ per capita income of region, and $\mathrm{i}=$ higher region forming area.

If the economic growth rate of a region is combined systemically with the level of per capita income, then there will be an overview of the structure of regional economic growth. Analysis using these two indicators by Klassen is classified into four groups, each of which has different characteristics that can be seen in Table 2 .

Four classifications of regions according to Klassen: 1) If the GDP growth rate of a region $>$ gdp growth on average, as well as per capita income of the area $>$ average per capita income, then the area belongs to the group of advanced and fast growing regions. 2) If the GDP growth rate of an area $>$ GDP growth is average, but the per capita income of the area is $<$ the average per capita income, then the area belongs to the group of fast growing regions. 3 ) If the GDP growth rate of an area $<$ GDP growth is average, but the per capita income of the area is $>$ the average per capita income, then the area belongs to the group of developed but depressed regions. 4) If the GDP growth rate of an area $<$ GDP growth is average, but the per capita income of the area is < the average per capita income, then the area belongs to the group of less developed regions. where: git $=$ growth rate for $\mathrm{t}$ years in $\%$, Xio $=$ initial year value of variables calculated growth (e.g. GDP, sector, revenue, etc.), Xit = end-of-year value of variables calculated growth, and $\mathrm{t}=$ length of observation year.

$$
g_{i t}=\left[\left(\frac{X_{i t}}{X_{i o}}\right)^{1 / t}-1\right] * 100 \%
$$

Where: $g_{i t}=$ growth rate for $\mathrm{t}$ years in $\%, \mathrm{X}_{\mathrm{io}}=$ initial year value of variables calculated growth (e.g. GDP, sector, revenue, etc.), $\mathrm{X}_{\mathrm{it}}=$ end-of-year value of variables calculated growth, and $\mathrm{t}=$ length of observation year. 


\section{Results and Discussion}

Provinsi Bengkulu memiliki wilayah seluas 19.919,33 $\mathrm{km}^{2}$ dengan komposisi luas wilayah kabupaten/kota seperti pada Fig. 2.

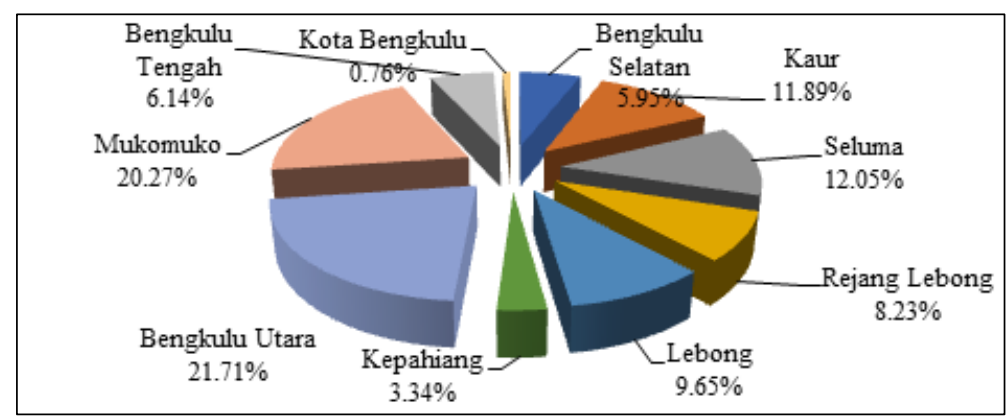

Source: Research results, processed data (2018)

Fig. 2. Composition of Area

When viewed from the composition of the population, the main regency with the highest population is North Bengkulu, followed by Rejang Lebong and finally South Bengkulu. While the expantion regency with the highest percentage of population is Seluma followed by Mukomuko and Kepahiang. Bengkulu Tengah is the region with the least population of only $5.76 \%$ of the total population of Bengkulu Province.

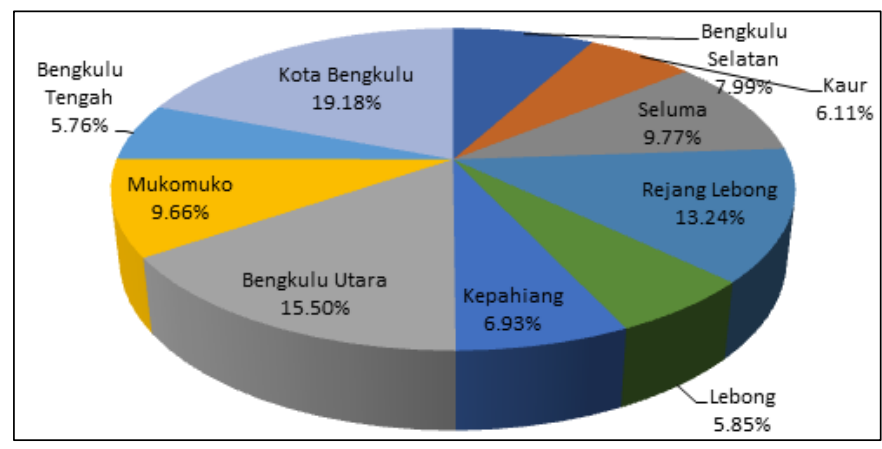

Source: Research results, processed data (2018)

Fig. 3. Persentage of Population in Bengkulu Province

There are several indicators that can be seen from the employment aspect of a region. Unemployment is one of the important indicators that has always been the focus of local government. In addition, wage levels are one of the benchmarks for the welfare of the people in the area. The Labor Force Participation Rate (TPAK) in Bengkulu Province is relatively equivalent, in the range of $70 \%$. The cities of Bengkulu and Mukomuko are the areas with the lowest TPAK, this means that in the area there are relatively more working-age residents who do not enter the labor force. The good of educational facilities is one of the factors of low TPAK, where the opportunity to go to school is better.

If viewed based on the parent regency, then it looks quite interesting phenomenon. South Bengkulu, Kaur and Seluma have almost the same TPAK and TPT numbers. This condition 
can indicate the diversity of existing employment conditions, such as community business fields, education levels, and wage levels that do not differ much.

In contrast to Rejang Lebong and North Bengkulu, where TPAK and TPT figures are relatively diverse. Lebong and Mukomuko become expantion regencys with relatively high TPT figures. Rejang Lebong and North Bengkulu have the lowest TPT figures among other regions. This may indicate that in those 2 regencys labor market conditions are relatively stable. Labor demand and supply are relatively balanced so there aren't many workers who don't get jobs.

Table 3. TPAK, TPT, Formal and Informal Sector Wages of Bengkulu Province

\begin{tabular}{lcccc}
\hline Kabupaten/Kota & $\begin{array}{c}\text { TPAK } \\
\mathbf{( \% )}\end{array}$ & $\begin{array}{c}\text { TPT } \\
(\mathbf{\%})\end{array}$ & $\begin{array}{c}\text { Upah Sektor Formal } \\
\text { (Rp/bulan) }\end{array}$ & $\begin{array}{c}\text { Upah Sektor Non Formal } \\
\text { (Rp/bulan) }\end{array}$ \\
\hline South Bengkulu & 71,71 & 3,09 & 2.568 .017 & 1.336 .270 \\
Kaur & 73,46 & 2,85 & 1.959 .283 & 1.241 .154 \\
Seluma & 71,79 & 2,95 & 2.363 .659 & 1.218 .400 \\
& & & & 1.414 .006 \\
Rejang Lebong & 76,82 & 1,69 & 2.303 .419 & 1.109 .248 \\
Lebong & 70,84 & 6,34 & 2.866 .338 & 1.301 .718 \\
Kepahiang & 75,02 & 3,08 & 1.982 .364 & 1.409 .854 \\
North Bengkulu & 68,90 & 2,72 & 2.155 .407 & 2.101 .844 \\
Mukomuko & 63,78 & 4,90 & 2.522 .213 & 1.485 .037 \\
Central Bengkulu & 71,54 & 3,48 & 2.105 .572 & 1.578 .028 \\
Bengkulu & 64,33 & 5,00 & 2.950 .842 & 1.533 .225 \\
Bengkulu Province & 70,06 & 3,51 & 2.510 .479 & \\
\hline \multicolumn{5}{c}{ Source: BPS of Bengkulu Province, 2018} \\
\end{tabular}

Regional economic performance analysis includes 3 indicators of Bappenas \& UNDP (2008), namely non-oil and gas GDP growth, GDP per capita and poverty, and added indicators of human resource quality, namely Human Development Index. When viewed from regional economic growth, Bengkulu city is the region that has the highest economic growth. In addition, Bengkulu also has the highest GDP/capita rate per year among other regions. As the center of government and provincial capital, Bengkulu city becomes the most advanced, most densely populated area and the area with the most complete infrastructure compared to other regions.

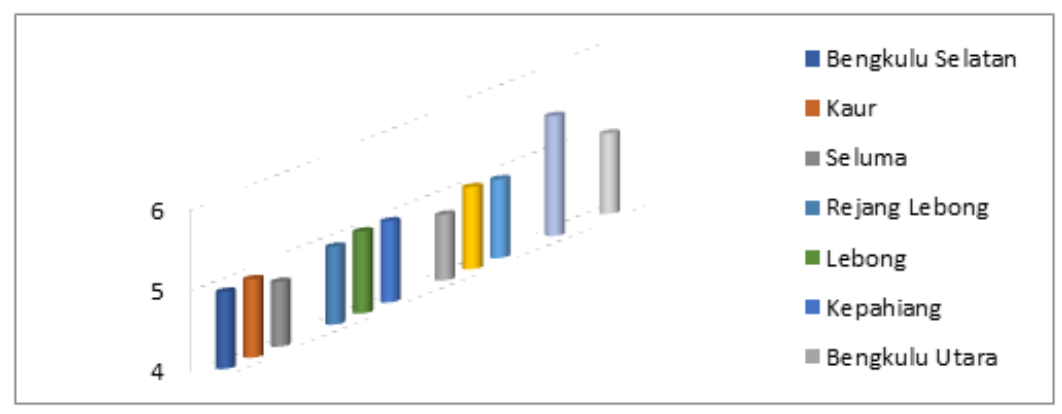

Source: BPS Provinsi Bengkulu, processed data, 2018

Fig. 4. Persentage of Economic Growth in Bengkulu Province 
It is clear that the economic growth of each of the main regencys is under the capubaten of its expantion. This implies that the economic condition of the main regency is relatively stable and saturated, in contrast to the expantion regency which is still experiencing relatively rapid growth.

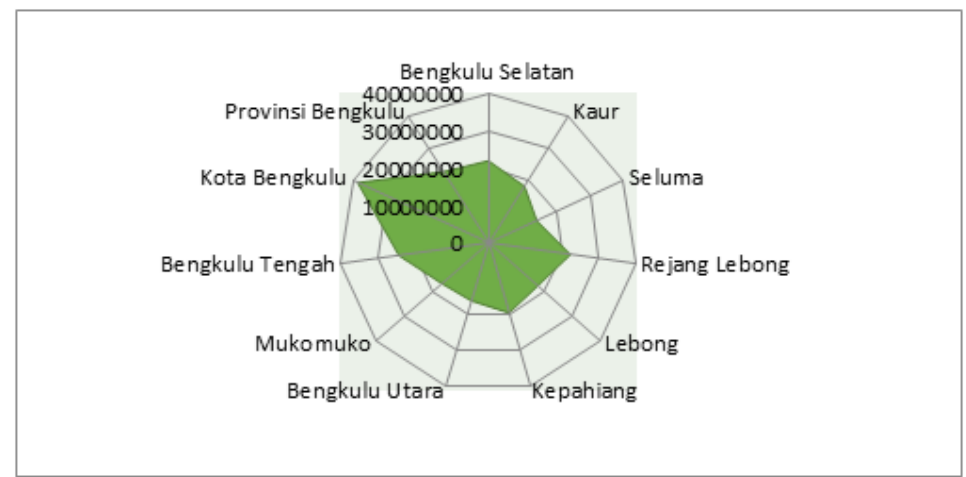

Source: BPS of Bengkulu Province, processed data, 2018

Fig. 5. GRDP per Capita/year in Bengkulu Province

In contrast to economic growth, the GRDP/capita of the main regency is relatively higher than the expantion regency, except North Bengkulu which is under Central Bengkulu. For South Bengkulu and Rejang Lebong, the GRDP/capita is above the expantion regency

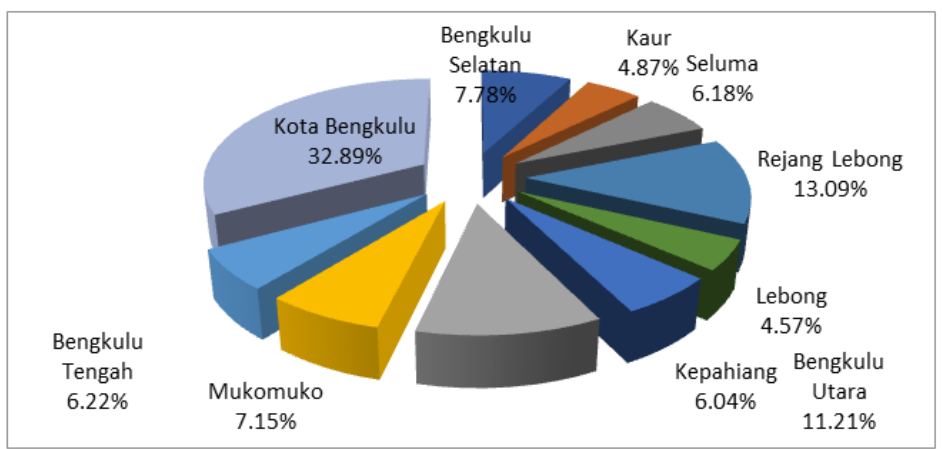

Source: BPS of Bengkulu Province, processed data, 2018

Fig. 6. Ratio of Regency/City PRDP to GRDP of Bengkulu Province

From Figure 6, you can see the ratio of regency/city GRDP to GRDP of Bengkulu Province. Bengkulu city is the largest contributor of GRDP. If you look at the condition of the main regency, it appears that both Rejang Lebong and North Bengkulu have a relatively higher GRDP ratio compared to other regencys. In contrast to South Bengkulu, which only accounts for $7.78 \%$ of GRDP.

The expantion area derived from the main regency of North Bengkulu seems to have a fairly good ratio, where Mukomuko becomes the expantion regency with the largest GRDP contribution, followed by Bengkulu Tengah. While the other 4 regencies only have donations in the range of 4.5 to $6 \%$. Further comparisons are made on the aspect of poverty. The percentage of poor people and gini ratio figures can be seen in Fig. 7 and 8. 


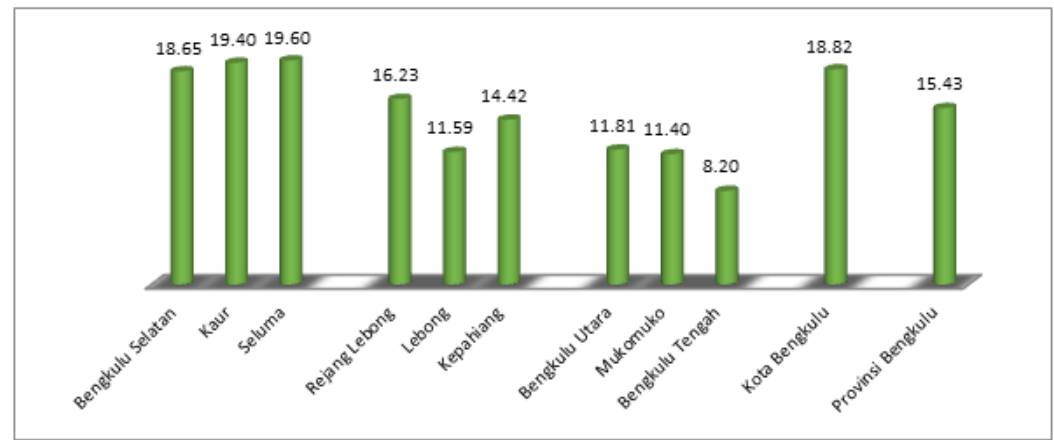

Source: BPS of Bengkulu Province, processed data, 2018

Fig. 7. Persentage of Poor Population by regency and Province

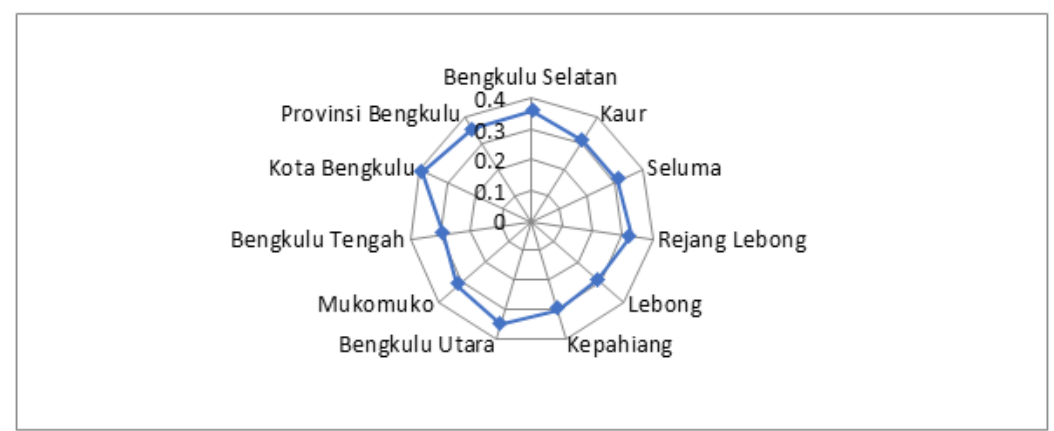

Source: BPS Provinsi Bengkulu, processed data, 2018

Fig. 8. Gini Rasio of Bengkulu Province

When viewed from the percentage of poor people, it is seen that South Bengkulu and its expanding regencys have a relatively high percentage of poor people compared to other regencys/cities. Kaur, Seluma and Bengkulu Selatan are the 3 regencies with the highest percentage of poor people in Bengkulu Province. On the other hand, the main regency with the lowest percentage of poor people is North Bengkulu where Bengkulu Tengah is the regency with the lowest percentage of the poor population overall at $8.20 \%$.

From Fig. 7 can be seen all the parent regencys have a gini ratio above the regency as a result of its expantion. This can be due to the diverse population in the main regency both in terms of work, education and income. It can also be seen that Bengkulu city has the highest gini ratio among other regions. This is also due to the dense population, the variety of jobs, business fields and education of residents in the area. Bengkulu Tengah is the area with the lowest gini ratio, which indicates that the inequality of population expenditure is relatively more evenly distributed than other regions. 


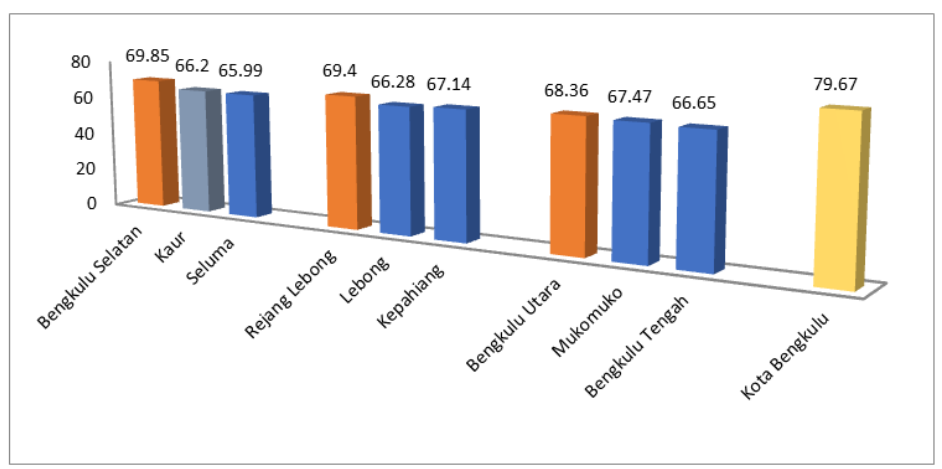

Source: BPS Provinsi Bengkulu, processed data, 2018

Fig. 9. Human Development Index (HDI) of Bengkulu Province

One measure of the quality of human resources of an area is the Human Development Index (HDI). If observed, 3 parent regencys have HDI values above the regency as a result of its expantion. This indicates that the welfare, education and health conditions that are indicators of HDI in the main regency are still relatively higher than the new regencys as a result of the expantion. This can certainly be understood because the condition of supporting infrastructure in the main regency of course the condition is relatively better than the new area. This includes the location of government centers and economies that have existed and developed in the past compared to new areas.

Bengkulu city becomes the area with the highest HDI value. In addition to being the capital of the province that is the center of government, Bengkulu city is also a center of economic activity supported by transportation facilities, information and other supporting economic activities. In addition, education and health infrastructure in Bengkulu city is relatively better and complete than existing regencys, thus making Bengkulu as the region with the highest per capita income and having better quality of education and health.

\section{Regency/City Classification Analysis}

Classification of regencys / cities is carried out by using Klassen Typology. The variables used are regency/city economic growth rate and per capita income level (GRDP). The comparative data used is the condition of the parent regency before the expantion, so that an overview of the economic growth structure of each parent regency and its expantion compared to the condition before the expantion. South Bengkulu Regency was expanded by adding 2 new regencys. After the expantion, it can be seen that South Bengkulu as the main regency and Kaur as the expantion kabuapten have a rate of economic growth and GRDP/ capita above South Bengkulu before it is expanded. Seluma is an area with a lower GRDP/capita even with a better economic growth rate.

\begin{tabular}{|c|c|c|}
\hline${ }_{\mathbf{Y}} \mathbf{R}$ & $\mathrm{Ri}>3.19 \%$ & $\mathrm{Ri}<3.19 \%$ \\
\hline $\begin{array}{l}\mathbf{Y i}>2.01 \text { million } \\
\mathbf{Y i}<2.01 \text { million }\end{array}$ & $\begin{array}{c}\text { South Bengkulu } \\
\text { Kaur } \\
\text { Seluma }\end{array}$ & \\
\hline
\end{tabular}

Source: Research results, processed data 
The same condition happened to Rejang Lebong. Rejang Lebong as the main regency also experienced an increase above the previous condition. On the other hand, Lebong became a expanding regency with a good rate of economic growth but gdp /capita was under preexpantion conditions.

Table 5. Classification of Regions of Rejang Lebong

\begin{tabular}{ll}
\multicolumn{1}{|l}{$\mathbf{R}$} & $\mathbf{R i}>\mathbf{3 . 7 4 \%} \quad \mathbf{R i}<\mathbf{3 . 7 4 \%}$ \\
\hline $\mathbf{Y i}>$ 4.56million & $\begin{array}{l}\text { Rejang Lebong } \\
\text { Kepahiang }\end{array}$ \\
$\mathbf{Y i}<\mathbf{4 . 5 6 m i l l i o n}$ & Lebong \\
\hline \multicolumn{2}{l}{ Source: Research results, processed data }
\end{tabular}

North Bengkulu regency is the parent district that experienced 2 expantions in different years. In 2003 North Bengkulu was expanded into 2 regencies namely North Bengkulu and Mukomuko.

Table 6. Classification of Regions of North Bengkulu

\begin{tabular}{cll}
$\mathbf{Y}_{\mathbf{Y i}>\mathbf{2 . 3 4 m i l l i o n}} \mathbf{R}$ & \multicolumn{1}{c}{$\mathbf{R i}>\mathbf{4 . 2 7 \%}$} & $\mathbf{R i}<\mathbf{4 . 2 7 \%}$ \\
$\mathbf{Y i}<\mathbf{2 . 3 4 m i l l i o n}$ & Bengulu Utara & \\
& &
\end{tabular}

Source: Research results, processed data

When expanded into 2 regencies, both North Bengkulu and Mukomuko recorded improved economic performance. It can be seen from the economic growth rate and GRDP per capita which became higher compared to North Bengkulu before it was expanded.

Central Bengkulu Regency became the youngest regency in Bengkulu Province, after it was formed in 2008 as a result of the expantion of North Bengkulu Regency. Classification of regions originating from the main district of North Bengkulu after becoming 3 regions can be seen in Table 7.

Table 7. Classification of Regions of Central Bengkulu

\begin{tabular}{cl}
$\mathbf{Y}$ & $\mathbf{R}$ \\
$\mathbf{Y i}>\mathbf{3 . 0 1 1}>\mathbf{7 . 3 9 \%} \%$ & \multicolumn{1}{c}{$\mathbf{R i}<\mathbf{3 . 1 9 \%}$} \\
$\mathbf{Y i}<\mathbf{3 . 0 1}$ million & Mukomuko \\
\hline \multicolumn{2}{c}{ Source: Research results, processed data }
\end{tabular}

The expantion of the region in 2008 again divided the north Bengkulu region into 2 and gave rise to Bengkulu Tengah Regency as the youngest district in Bengkulu Province. The classification conducted in 2009 shows that North Bengkulu has decreased both from the economic growth rate and GDP per capita. This can happen because the area that becomes the new district is a relatively large economic growth development area and GDP for North Bengkulu before.

From 3 regions from the same parent district, it appears that the district has a higher GDP per capita than the parent district. Meanwhile, in terms of economic growth, the three regions 
experienced a slowdown compared to the growth rate of North Bengkulu before Bengkulu Tengah became a new district.

Overall, regional classification is carried out for 2018 where the comparative value is GDP/capita and economic growth rate of Bengkulu Province. From the classification results can be seen that the 3 parent districts are in the lowest quadrant. This indicates that the performance of the parent district in general is below the district/city average. Bengkulu Tengah became the district with the highest GDP/capita rate compared to other regencies and main districts.

South Bengkulu Regency and its expantion districts (Kaur and Seluma) are in the lower quadrant. Meanwhile, Lebong, Kepahiang and Mukomuko showed relatively better economic growth even though the GRDP/capita rate was below average.

Table 8. Classification of Regency/City in Bengkulu Province

\begin{tabular}{|c|c|c|}
\hline $\mathrm{Y}_{\mathbf{Y}} \mathbf{R}$ & $\mathrm{Ri}>4.99 \%$ & $\mathrm{Ri}<4.99 \%$ \\
\hline$Y \mathbf{Y}>22.5$ million & $\begin{array}{l}\text { Regency/city advanced and } \\
\text { growing fast: Bengkulu }\end{array}$ & $\begin{array}{l}\text { Regency/city advanced but growing } \\
\text { slow: Central Bengkulu }\end{array}$ \\
\hline$Y \mathbf{Y}<22.5$ million & $\begin{array}{l}\text { Fast growing regency/city : } \\
\text { Lebong., Kepahiang \& } \\
\text { Mukomuko }\end{array}$ & $\begin{array}{l}\text { Underdeveloped regency/city: } \\
\text { North } \\
\text { Bengkulu, Rejang Lebong, South } \\
\text { Bengkulu, Seluma \& Kaur }\end{array}$ \\
\hline
\end{tabular}

To see the development of development inequality in Bengkulu Province, the Williamson Index (WI) is calculated for the point of 2018. It appears that WI has not changed from 2016. The WI number is still at 0.37 , above the WI in 2002 before the expantion of the region was carried out in Bengkulu Province.

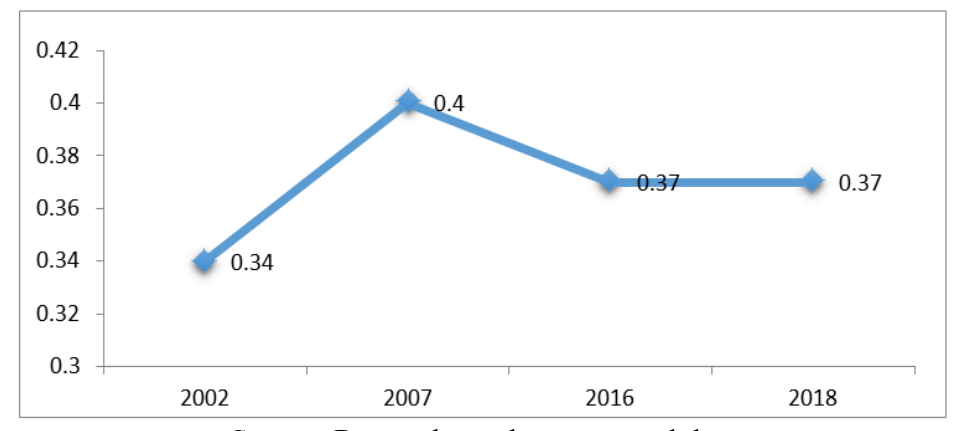

Source: Research results, processed data

Fig. 10. Indeks Williamson Provinsi Bengkulu

Development inequality that is relatively unalted should get more attention from local governments, both the district / city government and Bengkulu Province. The local government, especially Bengkulu Province, is expected to focus on improving the welfare condition of the community without prejudice to equitable development so that the objectives of regional expantion, one of which is the equality of the welfare of local communities can be achieved. This can be done by providing support and encouragement for districts / cities, especially the expantion districts in building areas through the construction of infrastructure, and policies that support the development process. 


\section{Conclusion}

Based on the results of the analysis and previous discussion, conclusion are:

a. In general, the parent district has an area and the number of pnduduk, the ratio of GDP to provincial GDP and HDI figures are higher than the expantion district.

b. In terms of economic growth, the main district is relatively lagging behind the expantion district. GDP / capita of some districts overtaking the GDP / capita of the parent district. From the poverty rate, only South Bengkulu has a figure below its expantion district, while Rejang Lebong and North Bengkulu have higher poverty rates.

c. From the classification of regions can be concluded that in general after the expantion occurred, the parent district experienced improvements both from economic growth and GDP / capita compared to before the expantion. However, at the end of the year observations showed that all the parent districts were in the lowest quadrant. This indicates that the expantion district is relatively well developed.

d. Development inequality in Bengkulu Province in 2016 to 2018 has not changed (IW figure of 0.37). This figure is still above the WI in 2002 where the expantion of districts in Bengkulu Province has not been implemented.

\section{Limitations and Suggestions}

The limitations in this study is only limited to analizing using Williamson Index and Klassen Typology. The further researchers can study the other method with a wider scope and adding the data from other province. Based on this research, there are several suggestions that the researcher wants to convey, including:

a. In an effort to improve the regional economic growth of the Bengkulu Province, an area expantion can be lead as a good issue. This expantion causing improvement of local government performance. Furher, the smaller area giving a comfort and touchable zone for government to create the better policy based on their own theritory.

b. In order to minimize insignificant research results and to having deeply conclusion, next the reseach can input some of variabel that having relationship with regional economic growth, for example by processing data using least square or the others.

\section{References}

[1] Adisasmita. R. Pengembangan Wilayah Konsep dan Teori, First Edition. Graha Ilmu: Yogyakarta (2008).

[2] Arianti, N. N \& Cahyadinata, I. Kajian Dampak Pemekaran Wilayah Terhadap Kinerja dan Pemerataan Ekonomi Daerah Pesisir di Provinsi Bengkulu, Laporan Penelitian, Fakultas Pertanian Universitas Bengkulu (2013).

[3] Armstrong. H. \& Taylor. J. Regional Economics and Policy, 3th edition. Blackwell Publisher: UK (2001).

[4] Arsyad. L. Ekonomi Pembangunan, Four Edition Keempat. STIE YKPN: Yogyakarta (1999).

[5] Arsyad. L. Pengantar Perencanaan dan Pembangunun Ekonomi Kabupaten/Kota, Second Edition. BPFE-UGM: Yogyakarta (2005).

[6] Bappenas \& UNDP. Studi Evaluasi Dampak Pemekaran Daerah 2001-2007, Bridge: Jakarta (2008). 
[7] BPS. Provinsi Bengkulu dalam Angka 2018. Badan Pusat Statistik Provinsi Bengkulu (2018).

[8] BPS.Tinjauan PDRB Kabupaten/Kota Provinsi Bengkulu 2014-2016. Badan Pusat Statistik Provinsi Bengkulu (2017).

[9] BPS. Provinsi Bengkulu dalam Angka 2008. Badan Pusat Statistik Provinsi Bengkulu (2008).

[10] BPS. Provinsi Bengkulu dalam Angka 2003. Badan Pusat Statistik Provinsi Bengkulu (2003).

[11] Bendavid-Val. A. Regional and Local Economic Analysis for Practitioners. $4^{\text {th }}$ edition. Praeger (1991).

[12] Blakely. E. J. \& Bradshaw. T. K. Planning Local Economic Development: Theory and Practice. $3^{\text {rd }}$ edition. Sage Publications. USA. (2002).

[13] Dhyatmika, W. K \& Atmanti, H.D. Analisis Ketimpangan Pembangunan Provinsi Banten Pasca Pemekaran. Diponegoro Journal of Economics, Vol 2(2). https://ejournal3.undip.ac.id/index.php/jme/article/view/2927/2827 (2013).

[14] Herawati, N. R., Pemekaran Daerah di Indonesia, http://ejournal.undip.ac.id

[15] Hoover. E.M. \& Giarratani. F. An Introduction to Regional Economics, 3th edition. Alfred A. Knopf: New York. (1984).

[16] Jhingan, M. The Economics of Development and Planning (With Special Reference to India). $\quad$ Retrieved from http://agris.fao.org/agrissearch/search.do?recordID=XF2015046756 (1985).

[17] Kuncoro. M. Metode Riset untuk Bisnis dan Ekonomi: Bagaimana meneliti \& menulis tesis? Erlangga. Jakarta. (2003).

[18] Kuncoro. M. Perencanaan Kabupaten/kota (Bagaimana Membangun Ekonomi Lokal. Kota dan Kawasan?) Salemba Empat: Jakarta (2012).

[19] Putri N.T \& Almahmudi, A. Analisis Ketimpangan Pembangunan di Provinsi Bengkulu (Telaah Posisi 3 Kabupaten Induk), Laporan Penelitian. (2018).

[20] Santika, R.H., Santoso, B,. \& Mahmudi, H. Analisis Dampak Pemekaran Daerah Terhadap Kinerja dan Pemerataan Ekonomi di Kabupaten Lombok Utara. Jurnal Ilmu Pemerintahan, Vol 3(1). https://doi.org/10.24905/jip.3.1.2018.15-23 (2018).

[21] Udiarto, A. K. Karakteristik Pengembangan Wilayah Sebelum dan Sesudah Pemekaran Kabupaten Jayapura. Jurnal Wilayah dan Lingkungan, Vol 3(2). https://doi.org/ 10.14710/jwl.3.2.121-130 (2015).

[22] Widodo. T. Perencanaan Pembangunan: Aplikasi Komputer (Era Otonomi Kabupaten/kota). UPP STIM YKPN. Yogyakarta. (2006).

[23] Winata, G.A. Dampak Pemekaran Wilayah Terhadap Perkembangan Perekonomian dan Kinerja Pemerintah Daerah Kota/Kabupaten di Provinsi Banten, Skripsi, Departemen Ilmu Ekonomi, Fakultas Ekonomi dan Manajemen IPB. (2016). 